\title{
EFFECT OF CORONAVIRUS (COVID-19) PANDEMIC ON MARKETING MIX (4Ps)
}

\author{
Ansere Joel Kwame Owusu, A.I. Ukhova \\ South Ural State University, Chelyabinsk, Russian Federation
}

\begin{abstract}
Considering how the coronavirus pandemic has affected business and social life of all countries of the world, it is necessary to study the extent to which this pandemic has caused damage to businesses. This article studies the effect of the coronavirus pandemic on price, product, place and promotion as these elements form the basis of any marketing mix. In this case, the study highlights how the coronavirus pandemic has caused a rise in prices of some goods termed as the necessities in the period of the pandemic due to limited supply. In addition, the selection of products has shifted to mostly groceries, household supplies, gym equipment, health supplies, sanitizers and face masks, and as a result, these products are the best-selling products during the coronavirus pandemic. Moreover, due to the requirements of social distancing, closure of retail shops and order stay-at-home recommendation to prevent the spread of the virus, consumers have been greatly engaged in online retailing as the most effective and safe means of purchasing during this period. The study also reveals that product and brand promotion is failing as consumers tend to save their money due to the uncertainty of when things are to get back to normal, and this has resulted in the act of ignoring discount coupons by consumers. E-mail marketing is also failing as consumers get bored with the bunch of e-mails they receive from brands, and the only information that seems to catch their attention is the one related to the coronavirus. Marketing agencies have resorted to animation and others for making adverts other than the usual real-life TV adverts and Still cam adverts due to the enforced social distancing requirements to prevent the spread of the virus.
\end{abstract}

Keywords: Coronavirus pandemic, Marketing mix, Price, Place, Promotion, Product.

\section{Introduction}

The world has been in a state of worry and fear as the COVID-19 disease keeps spreading from one country to the other. The virus has claimed a lot of lives and has put the global economic and social activities on hold where there have been laws enacted by various countries to forbid local and international travel and social gathering to prevent the spread of the disease.

Businesses have been greatly affected by the COVID 19. Apple as one of the global tech giants has been forced to temporarily close all stores outside of China where the pandemic originated (Eadicicco, 2020).

The COVID-19 disease originated from China has affected almost every part of the world (Schumaker 2020 \& Davidson, 2020).

According to the World Health Organisation, the coronavirus disease (COVID-19), is an infectious disease caused by a newly discovered coronavirus and most people infected with the COVID-19 virus will experience mild to moderate respiratory illness and recover without requiring special treatment.

Stöppler (2018), also claims that the coronavirus is a type of common virus that infects humans, typically leading to an upper respiratory infection (URI.). Therefore, seven different types of human coronavirus have been identified of which most people will be infected with at least one type of coronavirus in their lifetime. This means that every individual is at risk of contracting the virus at a certain point and time in his or her life.

According to Q\&A on coronaviruses (2020), the most recently discovered coronavirus causes coronavirus disease COVID-19. The virus spreads from person to person nearby through droplets of body fluids of an infected person, coughs and sneezes and the symptoms manifest between $1-14$ days after contracting the disease (Al Jazeera 2020).

On March 11, the World Health Organisation declared the COVID-19 disease a pandemic as it has affected over 110 countries with over 118,000 cases of the illness (Ducharme, 2020, Cucinotta \& Vanelli, 2020).

According to the BBC, by $3^{\text {rd }}$ April 2020, the total number of the CPVID-19 cases had surpassed 1 million, showing no signs to decrease anytime soon.

According to (Secon, Woodward, \& Mosher, 2020), the total number of global cases on COVID-19 had also surpassed 1.6 million by April 10, 2020.

As panic over the pandemic spreads globally, more businesses are facing difficult choices thus to close up business entirely, adhering strictly to socialdistancing recommendations; stay open; or something in between (Testa, Maheshwari, \& Friedman, 2020). This pandemic has affected operations of various businesses and organisations which includes their marketing activities and it has caused a shrink to busi- 
nesses, as global economies are also experiencing economic contraction (Semuels, 2020). There have been ups-and-downs of global stock markets recently, and have witnessed the reports on the catastrophic effect of the crisis on airlines and shipping across the world. Also, production facilities in Europe are compelled to slow down or halt their production cycle due to shortages of supplies from China (Blommaert, 2020).

Furthermore, Bloomaert (2020) asserts that China's exports took a sharp downturn in January and February 2020 as a direct effect of the epidemic which at that time had not become a pandemic, and its effects are felt across the world, which perhaps the most ironic example could be the fact that labs in charge of COVID19 testing around the world are running out of supplies since much of the diagnosing equipment are produced in China or by manufacturers whose supply chains involve Chinese partners.

As a result, this has also affected a lot of companies who produce and sell consumer goods, with their supply chains in China and this includes the marketing mix of their marketing strategy. This write up is a one that employs the qualitative approach that employs a statistical inference to draw conclusions from related elements.

\section{Literature review}

Initially, the traditional concept of the marketing mix includes Price, production, promotion and place which could also be referred to as the 4Ps (Suryaningsih \& Nohong, 2019).

The four P's were designed by E. Jerome McCarthy in the 1960s, and this classification has been used throughout the world to an extent that most business schools teach this concept and are also considered as the foundation of the marketing mix (Kenton, 2019). The Marketing Mix is referred to as the set of tactical marketing tools that's Price, Product, Place and Promotion, that a business blends to produce the response it wants in the target market (Kotler\&Armstrong, 2012). It is about providing the right product in the right place, at the right time, and the right price. Therefore, the four P's (Price, Product, Place and Promotion are combined and implemented by businesses to create a desired marketing strategy. Price seems to be an important factor in the promotion mix and Kotler et al. (2006) simply define price as: "the amount of money charged for a product or service. So, the price of a product equates the amount the consumer pays for that product.

A product is the tangible things a company offers their customers to satisfy their needs or wants and every successful company considers the product's form, functionality, features and benefits from the stance of the consumer (Ahmed, 2015). Some of these tangible products may include clothes, smartphones, shoes, cars, etc. A product serves as a bundle of benefits that are attained by consumers in an exchange transaction (Blackwell et. Al. 2006).
According to Kotler (2008), one of the keys to success in place and this begins by choosing the community where the business will operate. Morrison (2002) defines place as a physical place and a distribution channel where a product could be available and accessible to consumers through the company's intermediaries.

Lastly, promotion can also be called "communication mix" (Bowie and Buttle, 2004) or "promotion mix" (Kotler et al., 2006) that consist of a variety of promotional tools like advertising, sales promotion, brochures, loyalty cards, sponsorship, point of sale materials, sampling, websites direct, marketing and others.

\section{Coronavirus and the marketing mix}

\section{a. Price}

In light of the COVID-19 outbreak that originated from China, on the $10^{\text {th }}$ February 2020, The Wall Street Journal reported consumer inflation that reached it's highest since 2011. China's consumer price index rose $5.4 \%$ in January, after rising $4.5 \%$ in December, according to CEIC Data and this rise comes after economic activities have been curtailed in most parts of the country by the coronavirus outbreak, which led to some factories being temporarily closed and travel restrictions within the country (Pound, 2020). Food prices in China, in February, surged $21.9 \%$ from a year earlier, outpacing January's $20.6 \%$ gain and hitting the highest level since April 2008, when food prices jumped $22.1 \%$, according to data service provider Wind, (Marketwatch, 2020 and Cheng, Qi, Wang, \& Zhu, 2020)

According to the Financial Times, On the Amazon website, hand sanitizer and respiratory masks were at a point sold at more than $2000 \%$ mark up and also a pack of 20 masks made by a manufacturer called "3M" was on sale at $\$ 387$ compared to the normal retail price of about $\$ 15$ while a pack of 24 , $20 \mathrm{z}$ bottles of Purell hand sanitizer was sold at $\$ 400$ despite the actual price of less than $\$ 10$ (Lee, 2020).

Also, Lee (2020). Asserts that third-party sellers on Amazon are also hiking the prices of these particular products.

Also, Meyersohn (2020), confirms that the coronavirus pandemic has skyrocketed the price of eggs to a $14 \%$ increase at Morton Williams stores in New York as the company is frustrated that it's paying double for eggs from its suppliers.

Furthermore, Mukherjee (2020) also reports that, in Kolkata (India), consumer electronics companies plan to increase prices of refrigerators, airconditioners, microwave ovens and washing machines from March due to higher component prices amid short supplies from coronavirus-hit China and large manufacturers including LG, Voltas, Samsung, Haier and Panasonic have decided on a $3-5 \%$ in price.

\section{b. Product}

China, which is the second-largest economy in the world has all but halted its production of consumer 


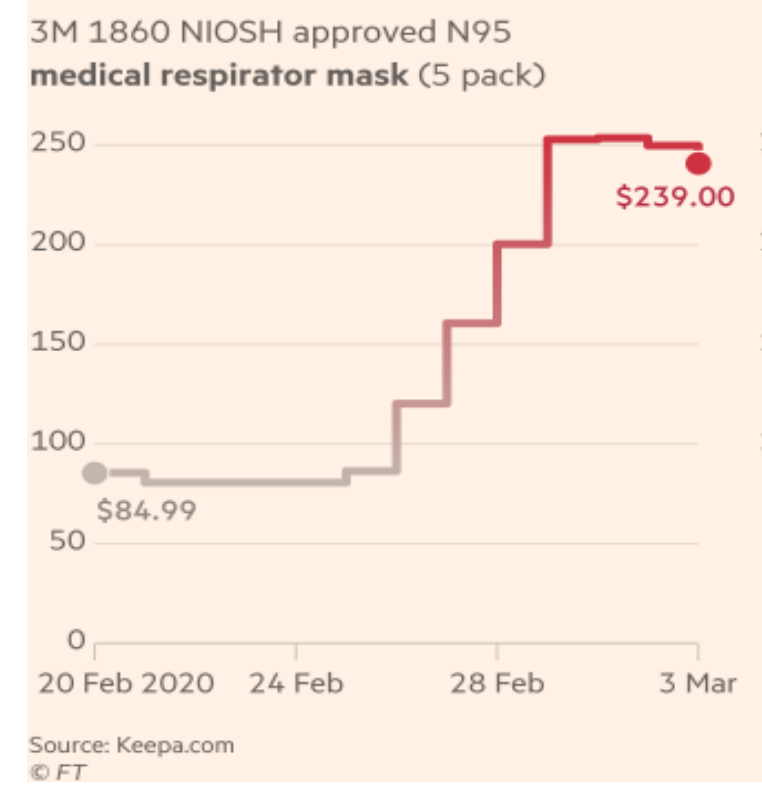

Purell Advanced hand sanitiser gel,

fragrance free, $1000 \mathrm{ml}$ refill

200

150

100

50

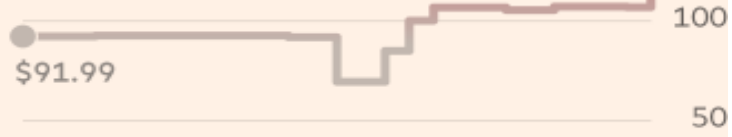

0

6 Feb 2020

$20 \mathrm{Feb}$

3 Mar

Pic. 1. Price Hike of Face Masks and Hand Sanitizers on Amazon.

https://www.ft.com/content/8db033ac-5d11-11ea-b0ab-339c2307bcd4

goods such as phones, clothing, and automobiles for the past several weeks due to the outbreak of the coronavirus (Ghaffary \& Molla, 2020).

As the virus keeps spreading it has affected a lot of factory activities in China to fall at a record rate in February 2020, as manufacturers closed their operations to contain the spread of coronavirus and the country's official measure of manufacturing activity the Purchasing Manager's Index (PMI) - dropped to 35.7 from 50 in January thus affecting companies like Apple, Diageo, Jaguar, Land Rover and Volkswagen, which rely on China's production and consumer market (Prescott, 2020).

According to Zinberg (2020), the COVID-19 disease might cause a shortage in generic drugs, APIs and PPEs like surgical gowns, gloves, masks and respirator, as there are disruptions in the supply due to limited manufacturing activities in China since it is the largest manufacturer in the world.

As the virus keeps affecting companies tied to the Chinese supply chain, some manufacturers have already had to slow down production in their plants outside of China, and the list increases every day. For example, Fiat, Chrysler Automobiles NV announced on February 14 that it is temporarily halting production at a car factory in Serbia because the parts for production comes from China. Similarly, Hyundai said that it decided to suspend its production lines from operating at its plants in Korea as a result of the disruptions in the supply of parts due to the coronavirus outbreak in China (Haren \& Simchi-Levi, 2020). This signifies that products could be delayed for a while to make it to the market for consumers.

Also, Apple's supply chain in China slowed down due to the virus outbreak, which led to iPhone and AirPods supply constraints, resulting in Apple limiting iPhone purchases to two per customer on its online store in several countries and in early March, the company warned retail employees about shortages of replacement iPhones (Gurman \& Wu, 2020). Apple announced the new Ipad Pro 2020 on the $18^{\text {th }}$ of March 2020 with a new keyboard accessory but as the iPad already started selling, the keyboard was not ready to on sale yet until the May, that's an unusual delay due to the constraints on Apple's supply chain (Gurman \& Wu, 2020).

Also, the Business Insider reported that the launch of Apple's next major iPhone, believed to be called the iPhone 12, could be delayed by one or two months as both the company's business operations and supply chain recover following disruptions related to the coronavirus pandemic (Eadicicco, 2020).

Etherington (2020) reported that Amazon temporarily suspended its Fulfillment by Amazon Program (FBA) to allow prioritize shipment of household staples, medical supplies and other high-demand products due to the coronavirus outbreak.

This was confirmed from Amazon's official seller central page on their website (https://sellercentral.amazon.com/gp/help/external/help.html?itemID=GF37V7Q BB8WSVF43\&tag=bisafetynet2-20\&) and this shows how the outbreak has caused a turn in the type of product Amazon prioritizes for sale.

In the $\mathrm{UK}$, the $\mathrm{BBC}$ report claims that the government only allows individuals to go and shop for necessities like food and medicine and other necessities. Therefore, only supermarkets, pharmacies, offlicences, petrol stations, newsagents, home and hard- 
ware stores and garages are supposed to operate (Wilson, 2020). This has sparked controversies among the people about what is considered a necessity for each person.

According to Wilson (2020), most supermarkets in the UK haven't told shoppers what should be classed as priority or essential goods but have put limitations on the number of items you can purchase of certain products which included paracetamol, toilet roll, hand sanitiser, baby milk, pasta, rice and canned goods.

An online article by Shevchenko (2020) confirms a situation in Russia where some goods have become harder to find amidst the coronavirus outbreak and thus shelves that were previously filled with buckwheat, rice, pasta and noodles, flour, and toilet paper sometimes look empty.

Spending has promptly shifted to staple items such as groceries and household cleaning supplies, away from apparel and accessories (Thomas, 2020). An analyzed data by Adobe Analytics, from trillions of visits to retail websites and millions of product stock keeping units, found out that online grocery purchases are leading the eCommerce boom and Among the most popular items in people's internet shopping carts are Health products, gym equipment, toilet paper and canned foods with to a $100 \%$ boost in sales for groceries, $807 \%$ boost in virus protection products such as gloves, masks and hand sanitizers, and a $217 \%$ boost in over the purchase of over the counter drugs (Brown, 2020). Also the purchase of gym equipment like kettlebells, dumbbells and treadmills a saw $55 \%$ boost (Brown, 2020).

\section{c. Place}

The time of coronavirus is proving to be a confusing moment for consumers. In an unusual act for US retailers, more than 90 stores across the country chose to close their doors for an unspecified period to prevent the spread of the deadly coronavirus in the US and after while a company like Walmart took measures to reduce working hours in their physical shops (Biron, 2020). The spread of the virus has compelled a lockdown and quarantine period across the globe.

In the moment of quarantine to prevent the spread of the coronavirus, stores selling essentials like food, drugs, household goods and, of course, toilet paper continue to sell out their inventories but stores selling general merchandise, apparel, home, footwear and other non-essentials are feeling the full impact of the quarantining (Shoulberg, 2020).

Neate \& Halliday (2020) claims that Many European countries and US states have forced the closure of all shops, except for those deemed essential, such as supermarkets, other food retailers and pharmacies.

Since shops are been closed across the world, consumers deemed it necessary to resort to online purchase and Pymnts (2020) asserts that the coronavirus has compelled most US consumers to shop online as they have transitioned from a digital-often world to a largely digital-most world in under a month across their "business and life as usual" activities amid the coronavirus. This is as a result of the stay-at-home orders issued by the governors of various states (Lee, 2020).

a study by Karter (2020) asserts that the pandemic crisis has accelerated the shift to online shopping, particularly for mobile thus overall, physical stores sales have declined by an average $-1.2 \%$, while online sales show an average $1.0 \%$ increase.

USA Today also reports an overall increase in online sales of $25 \%$ amidst the COVID-19 crisis depicting the great shift from physical retailing to online retailing.

\section{d. Promotion}

The magic promotion has on consumers seem to be failing during the coronavirus. Thomas, (2020) says that some companies are giving decent online deals and many retailers that did not offer free shipping are now offering it and even extending the period consumers can make returns amid the coronavirus pandemic and also even as companies send a $25 \%$ or $30 \%$ coupon to consumers' email, consumers are not responding to these coupons because the wariness surrounding the pandemic has prompted consumers to tighten their wallets.

According to Neil Saunders, the managing director of GlobalData Retail, companies can discount in a demand-weak environment but it doesn't matter in this period of the pandemic (Thomas, 2020).

Collins \& Hays (2020) reports in their article that, email marketing is working against companies and brands who are using them during this period of the coronavirus because it is not yielding any results since consumers are on the lookout for information related to the pandemic and so marketing experts agree that using the mass attention on COVID-19, or the coronavirus, as a marketing hook is, at best, unseemly.

CNBC reports that people took to Twitter to express their irritation at being sent marketing emails from companies they haven't heard from in years and most ad agency executives concur that trying to advertise during unprecedented times is a difficult balance (Handley, 2020).

Due to the coronavirus, there is a shift in the way of promotion where ads are done without real-life TV or still shots but instead, companies are shifting to the use of animation, illustration, CGI (computergenerated images), VFX (visual effects), motion graphics, compositing, stock footage, user-generated footage and more, as confirmed by Will Lion, a managing partner at BBH London in a brief to clients as he cited examples of an ad campaign for Audi, which was produced using CGI, and text-heavy ads for the Guardian newspaper, both done without shoots (Handley, 2020).

\section{Conclusion}

One can infer that the coronavirus pandemic has caused a great change in the lives of consumers due to 


\section{Маркетинг}

how uncertain the crisis seems. People are spending on essential goods necessary for the state in which the coronavirus pandemic has plunged the world into.

Even though essential products differ from person to person but we can realise that most individuals are buying the same category of products which are considered the most essential products at the moment, ranging from groceries, household staples, protective and health supplies and gym equipment, which lead almost every shopping list of consumers. Retailers selling products in these categories are making a lot of money from consumers by outrageously increasing the prices of these products than the usual prices they were sold at because of how limited these products have been since the outbreak of the coronavirus, and to the extreme, some are even out of stock at retail shops due to limited supply in the face of rising demand. The law of demand and supply asserts that when demand exceeds supply, prices rise and thus the absurd increase in prices (Kramer, 2020).

Also, this period of coronavirus, social distancing has become a rule and it has enforced the closure of many physical shops and retail businesses across the world leading to a boom in online retailing resulting in a $62 \%$ increase in online order for in-store-pickup as findings from Adobe Analytics show (Brown 2020).
The virus has done more harm than good to the product of companies as numerous companies had to stop production due to either shortage or limited parts for production as there was a disruption in their supply chain tied to China where the virus originated. This has caused delays in the product release and closure of some manufacturing plants and retail shops and one of the famous ones is Apple (Huguet, 2020).

Furthermore, the coronavirus has shifted the way people react to the promotion of consumer goods as people ignore discount coupons sent to their emails and others also getting bored with companies sending adverts to their emails. It is assumed that consumers are not interested in news and information that is not related to the coronavirus pandemic and so marketer are beginning to attach news and information to the ads they send to consumers to get their attention.

Marketing agencies are also resorting to animation, illustration, CGI (computer-generated images), VFX (visual effects), motion graphics, compositing, stock footage, user-generated footage for their adverts instead of real-life TV or still-shot adverts.

In a nutshell, the coronavirus pandemic has a tremendous effect on price, product, place and promotion of and it has also changed the behaviour of consumers as a result.

1. Coronavirus. (n.d.). Retrieved topics/coronavirus\#tab $=$ tab_1

2. Stöppler, M. C. (2018, December 11). Medical Definition of Coronavirus, Written by Doctors. Retrieved April 14, 2020, from https://www.medicinenet.com/script/main/art.asp?articlekey=22789

3. Q\&A on coronaviruses (COVID-19). (n.d.). Retrieved April 14, 2020, from https://www.who.int/newsroom/q-a-detail/q-a-coronaviruses

4. Al Jazeera. (2020, March 15). How does coronavirus spread and how can you protect yourself? Retrieved April 14, 2020, from https:/www.aljazeera.com/news/2020/01/coronavirus-spread-protect200130115539072.html

5. Ducharme, J. (2020, March 11). The WHO Just Declared Coronavirus COVID-19 a Pandemic. Retrieved April 14, 2020, from https://time.com/5791661/who-coronavirus-pandemic-declaration/

6. Cucinotta, D., \& Vanelli, M. (2020, March 19). WHO Declares COVID-19 a Pandemic. Retrieved April 14, 2020, from https://www.ncbi.nlm.nih.gov/pubmed/32191675

7. Schumaker, E. (2020, April 9). Timeline: How coronavirus got started: The outbreak spanning the globe began in December, in Wuhan, China. Retrieved April 14, 2020, from https://abcnews.go.com/Health/timelinecoronavirus-started/story?id=69435165

8. Davidson, H. (2020, March 13). First COVID-19 case happened in November, China government records show-report. Retrieved April 14, 2020, from https://www.theguardian.com/world/2020/mar/13/firstcovid-19-case-happened-in-november-china-government-records-show-report

9. Eadicicco, L. (2020, March 14). Apple's unprecedented decision to close all stores outside of China because of coronavirus may be a sign of what's to come. Retrieved April 14, 2020, from https://www.businessinsider.com/coronavirus-apple-china-covid19-outbreak-stores-closing-precaution-analysisprepare-2020-3

10. Coronavirus: Confirmed global cases pass one million. (2020, April 3). Retrieved April 14, 2020, from https://www.bbc.com/news/world-52144390

11. Secon, H., Woodward, A., \& Mosher, D. (2020, April 8). A comprehensive timeline of the new coronavirus pandemic, from China's first COVID-19 case to the present. Retrieved April 14, 2020, from https://www.businessinsider.com/coronavirus-pandemic-timeline-history-major-events-2020-3 
12. Testa, J., Maheshwari, S., \& Friedman, V. (2020, March 18). Which Clothing and Beauty Stores Have Closed? Retrieved April 14, 2014, from https://www.nytimes.com/2020/03/18/style/coronavirus-clothingbeauty-stores-closed.html

13. Semuels, A. (2020, March 18). Why the COVID-19 Financial Crisis Is Like No Other. Retrieved April 14, 2020, from https://time.com/5805526/coronavirus-economy-layoffs/

14. Patidar, M. (2019, August 30). Marketing Notes - The Marketing Mix. Retrieved April 14, 2020, from https://www.enotesmba.com/2013/03/marketing-notes-marketing-mix.html

15. Blommaert, J. (2020, March 6). COVID19 and Globalization. Retrieved April 15, 2020, from https://www.academia.edu/42174919/COVID19_and_Globalization

16. Suryaningsih, C. P., \& Nohong, M. (2019, May). ANALYSIS EFFECT OF 7P MARKETING MIX ON CONSUMER PURCHASE DECISIONS CASE STUDY IN BRITANIA EDUCATIONAL INSTITUTIONS. Retrieved April 15, 2020, from https://www.academia.edu/39958070/ANALYSIS_EFFECT_ OF_7P_MARKETING_MIX_ON_CONSUMER_PURCHASE_DECISIONS_CASE_STUDY_IN_BRITANIA _EDUCATIONAL_INSTITUTIONS

17. Ahmed, S. (2015). The Effects of Marketing Mix on Consumer Satisfaction: A Literature Review From Islamic Perspectives. Turkish Journal of Islam Economic, 2(1), 17-30. DOI: dx.doi.org/10.15238/ tujise.2015.2.1.17-30

18. Kotler, Philip and Gary Amstrong, 2008, Management Principles. Issue 12. Jakarta: Erlangga

19. Kotler, P. \& Bowen, J.T. \& Makens, J.C. (2006) Marketing for Hospitality and Tourism. The United State of America, Pearson Education

20. Blackwell, R.D. \& Minaid, P.W. \& Engel, J.F.(2006) Consumer Behaviour. 10th ed., China, Thomson South-Western

21. Morrison, A. (2002) Marketing Hotel Accommodation. Cited in: Verginies, C. and Wood, R. (eds) Accommodation Management Perspective for the International Hotel Industry. London, Thomson.

22. Bowie, D. \& Buttle, F. (2004) Hospitality Marketing an Introduction. China, Elsevier Butterworth Heinemann

23. Pound, J. (2020, February 10). Inflation in China is running rampant because of the coronavirus. Retrieved April 15, 2020, from https:/www.cnbc.com/2020/02/10/inflation-in-china-is-running-rampant-becauseof-the-coronavirus.html

24. MarketWatch. (2020, March 10). Coronavirus sends food prices soaring in China. Retrieved April 15, 2020, from https://www.marketwatch.com/story/coronavirus-sends-food-prices-soaring-in-china-2020-03-10

25. Lee, D. (2020, March 3). Amazon battles sharp price rises of coronavirus products. Retrieved April 15, 2020, from https://www.ft.com/content/8db033ac-5d11-11ea-b0ab-339c2307bcd4

26. Meyersohn, N. (2020, March 25). Egg prices are skyrocketing because of coronavirus panic shopping. Retrieved April 15, 2020, from https://edition.cnn.com/2020/03/25/business/egg-prices-supermarketscoronavirus/index.html

27. Mukherjee, W. (2020, February 27). Electronic goods set to get expensive amid short supplies from the virus hit China. Retrieved April 15, 2020, from https://economictimes.indiatimes.com/industry/consproducts/electronics/electronic-goods-set-to-get-expensive-amid-short-supplies-from-virus-hitchina/articleshow/74327481.cms?from=mdr

28. Coronavirus Helps Drive China's Consumer Prices to Highest Level in Over Eight Years. (2020, February 10). Retrieved April 15, 2020, from https://www.wsj.com/articles/coronavirus-helps-drive-chinas-consumerprices-to-highest-level-in-over-eight-years-11581314378

29. Cheng, J., Qi, L., Wang, B., \& Zhu, G. (2020, March 10). Coronavirus Sends Food Prices Soaring in China, as Producer Prices Slump. Retrieved April 15, 1992, from https://www.wsj.com/articles/coronavirussends-food-prices-soaring-in-china-as-producer-prices-slump-11583823262

30. Prescott, K. (2020, February 29). Chinese manufacturing hits record low amid coronavirus outbreak. Retrieved April 15, 2020, from https://www.bbc.com/news/business-5168917

31. Zinberg, J. (2020, March 20). The Virus and the Supply Chain. Retrieved April 14, 2020, from https://www.city-journal.org/coronavirus-pharmaceuticals-production

32. Haren, P., \& Simchi-Levi, D. (2020, February 28). How Coronavirus Could Impact the Global Supply Chain by Mid-March. Retrieved April 15, 2020, from https://hbr.org/2020/02/how-coronavirus-could-impactthe-global-supply-chain-by-mid-march

33. Ghaffary, S., \& Molla, R. (2020, February 26). Apple, Facebook, and Google stocks are falling after the surge in coronavirus cases. Retrieved April 15, 2020, from https://www.vox.com/recode/2020/2/20/21145803/ coronavirus-impacting-big-tech-business-apple-amazon-facebook-big-tech-impacted 


\section{Маркетинг}

34. Gurman, M., \& Wu, D. (2020, March 20). Apple's Supply Chain Woes Linger Even as China Recovers. Retrieved April 15, 2020, from https://www.bloomberg.com/news/articles/2020-03-19/apple-s-supply-chainwoes-linger-even-as-china-recovers?sref=BWbpWjRm

35. Eadicicco, L. (2020, March 26). Analysts predict the iPhone 12 could be delayed by up to 2 months because the coronavirus has disrupted Apple's iPhone testing process. Retrieved April 15, 2020, from https://www.businessinsider.com/apple-iphone-12-release-date-possible-delay-analyst-jpmorgan-2020-3

36. Etherington, D. (2020, March 17). Amazon limiting shipments of certain types of products due to COVID-19 pandemic. Retrieved April 16, 2020, from https://techcrunch.com/2020/03/17/amazon-limitingshipments-to-certain-types-of-products-due-to-covid-19-pandemic/

37. GP. (2011). Retrieved April 16, 2020, from https://sellercentral.amazon.com/gp/help/external/help. html?itemID=GF37V7QBB8WSVF43\&tag=bisafetynet2-20\&

38. Wilson, C. (2020, April 2). Coronavirus: Shoppers face 'essential items' confusion. Retrieved April 16, 2020, from https://www.bbc.com/news/uk-52097797

39. Shevchenko, N. (2020, March 19). Empty shelves due to coronavirus: Legit panic or sheer hysteria? Retrieved April 16, 2020, from https://www.rbth.com/lifestyle/331856-coronavirus-russia-shops

40. Biron, B. (2020, March 23). More than 90 major US retailers are temporarily closing stores in an unprecedented move to prevent the spread of the coronavirus. Retrieved April 16, 2020, from https://www.businessinsider.com/13-retailers-announce-temporarily-store-closures-to-fight-coronavirus-2020-3

41. Shoulberg, W. (2020, March 20). More Than 110 Retailers Have Now Shut All Their Stores Because Of Coronavirus. Retrieved April 16, 2020, from https://www.forbes.com/sites/warrenshoulberg/ 2020/03/18/more-than-110-retailers-have-now-shut-all-their-stores-because-of-coronavirus/\#43e90b9c2138

42. Neate, R., \& Halliday, J. (2020, March 23). UK government considers forcing non-essential shops to close. Retrieved April 16, 2020, from https://www.theguardian.com/business/2020/mar/23/governmentconsiders-forcing-non-essential-shops-to-close-reports-coronavirus

43. Karter, E. (2020, April 7). Consumers react to coronavirus crisis, increasingly move online. Retrieved April 16, 2020, from https://news.northwestern.edu/stories/2020/04/consumers-react-to-coronavirus-crisisincreasingly-move-online/

44. Pymnts. (2020, April 7). Consumers Go Mostly Digital During Coronavirus. Retrieved April 16, 2020, from https://www.pymnts.com/today-in-data/2020/consumers-move-to-digital-during-coronavirus-lockdowns/

45. Lee, A. (2020, April 7). These states have implemented stay-at-home orders. Here's what that means for you. Retrieved April 16, 2020, from https:/edition.cnn.com/2020/03/23/us/coronavirus-which-states-stay-athome-order-trnd/index.html

46. Thomas, L. (2020, March 23). Retailers are dangling deals online amid coronavirus, but shoppers may not show up. Retrieved April 16, 2020, from https://www.cnbc.com/2020/03/23/retailers-with-shuttered-storespush-online-deals-to-try-to-get-sales.html

47. Collins, A., \& Hays, K. (2020, March 24). Marketing in the Age of Coronavirus: The Dos and (Many) Don'ts. Retrieved April 16, 2020, from https:/wwd.com/business-news/media/coronavirus-business-impactmarketing-advertising-best-practices-1203542425/

48. Handley, L. (2020, March 31). 'Acts not ads': How firms should market themselves during the coronavirus crisis. Retrieved April 16, 2020, from https://www.cnbc.com/2020/03/27/how-firms-should-marketthemselves-during-the-coronavirus-crisis.html

49. Brown, D. (2020, March 31). Shopping while quarantined: Here's what people are ordering online during coronavirus. Retrieved April 16, 2020, from https://www.usatoday.com/story/money/2020/03/31/studywhat-people-ordering-online-during-coronavirus-crisis/5086640002/

50. Kramer, L. (2020, March 23). How Does the Law of Supply and Demand Affect Prices? Retrieved April 16, 2020, from https://www.investopedia.com/ask/answers/033115/how-does-law-supply-and-demandaffect-prices.asp

51. Huguet, K. (2020, March 27). Apple's COVID-19 Response. Retrieved April 16, 2020, from https://www.apple.com/newsroom/2020/03/apples-covid-19-response/

52. (2020, August 4). Q\&A on coronaviruses. Retrieved from https://www.who.int/news-room/q-a-detail/qa-coronaviruses 
Joel Kwame Owusu Ansere, graduate student, Department of Management, South Ural State University, Chelyabinsk, anserejoel@gmail.com

Antonina I. Ukhova, Candidate of Sciences (Economics), Associate Professor, Department of Management, South Ural State University, Chelyabinsk, ukhovaai@ susu.ru

Received 15 июня, 2020

Удк 339.138

DOI: $10.14529 / \mathrm{em} 200319$

\title{
ВЛИЯНИЕ ПАНДЕМИИ КОРОНАВИРУСА (COVID-19) HА МАРКЕТИНГ МИКС (4Ps)
}

\author{
Ансере Джоэл Кваме Овусу, А.И. Ухова \\ Южно-Уральский государственный университет, г. Челябинск, Россия
}

\begin{abstract}
Учитывая, как пандемия коронавируса затронула все уголки мира: и бизнес, и общественную жизнь - актуальным является изучение степени, в которой эта пандемия нанесла ущерб бизнесу. В статье авторами оценено влияние пандемии коронавируса на цену, продукт, распределение и продвижение, поскольку эти элементы составляют основу комплекса маркетинга. Проведенное исследование показывает, как пандемия коронавируса вызвала рост цен на некоторые товары, считающиеся необходимыми в период пандемии, из-за ограниченного предложения. Также спрос продуктов сместился в основном на продукты питания, товары для дома, оборудование для тренировок, товары для здоровья, дезинфицирующие средства и медицинские маски, и в результате эти продукты стали самыми продаваемыми продуктами в ситуации пандемии. Кроме того, из-за законов о социальном дистанцировании, закрытии розничных магазинов и рекомендациях оставаться дома для предотвращения распространения вируса потребители активно участвовали в розничной торговле через Интернет как наиболее эффективном и безопасном способе совершения покупок в этот период. Исследование также демонстрирует, что продвижение продуктов и брендов становится менее результативным, поскольку потребители, как правило, опасаются совершать покупки из-за неуверенности в том, когда ситуация стабилизируется и вернется в привычное русло, это привело к тому, что потребители стали игнорировать акционные предложения и другие стимулирующие мероприятия. Электронный маркетинг также потерпел неудачу, поскольку потребителей утомляет большое число рекламных писем, и единственная информация, которая, вероятно, привлекает внимание, связана с коронавирусом. Маркетинговые агентства прибегают к анимации и другим технологиям создания рекламы, отличной от обычных видео роликов и статичной рекламы, что обусловлено необходимостью социального дистанцирования для предотвращения распространения вируса.
\end{abstract}

Ключевые слова: пандемия коронавируса, маркетинг микс, цена, распределение, продвижение, продукт.

Ансере Джоэл Кваме Овусу, студент магистратуры, кафедра менеджмента, Южно-Уральский государственный университет (национальный исследовательский университет), anserejoel@ gmail.com

Ухова Антонина Ивановна, к.э.н., доцент кафедры менеджмента, Южно-Уральский государственный университет (национальный исследовательский университет), ukhovaai@susu.ru

Поступила в редакцию 15 июня 2020 2.

\section{ОБРАЗЕЦ ЦИТИРОВАНИЯ}

Ansere, Joel Kwame Owusu. Effect of Coronavirus (Covid-19) Pandemic on Marketing Mix (4Ps) / Ansere Joel Kwame Owusu, A.I. Ukhova // Вестник ЮУрГУ. Серия «Экономика и менеджмент». - 2020. - Т. 14, № 3. - C. 180-187. DOI: $10.14529 / \mathrm{em} 200319$

\section{FOR CITATION}

Ansere Joel Kwame Owusu, Ukhova A.I. Effect of Coronavirus (Covid-19) Pandemic on Marketing Mix (4Ps). Bulletin of the South Ural State University. Ser. Economics and Management, 2020, vol. 14, no. 3, pp. 180-187. DOI: $10.14529 / \mathrm{em} 200319$ 